\title{
Managing Fertilization of Bedding Plants: A Comparison of Constant Fertilizer Concentrations versus Constant Leachate Electrical Conductivity
}

\author{
Jong-Goo Kang \\ Department of Horticulture, Sunchon National University, Sunchon, South \\ Korea
}

\author{
Marc W. van Iersel ${ }^{1}$ \\ Department of Horticulture, University of Georgia, 1111 Miller Plant \\ Science Building, Athens, GA 30602
}

Additional index words. Begonia $\times$ semperflorens, EC, Petunia $\times$ hybrida, pourthrough, $\mathrm{pH}$, subirrigation

\begin{abstract}
In the last decade, there has been an increasing focus on maintaining the electrical conductivity (EC) of leachate of bedding plants within an optimal range. However, there has been no research determining whether an optimal leachate EC results in better growth than using constant fertilizer concentrations throughout the production period. To evaluate the effects of constant fertilizer concentrations and constant leachate EC on the growth of wax begonia (Begonia $\times$ semperflorens-cultorum Hort.) 'Cocktail mix' and petunia (Petunia $\times$ hybrida Hort. Vilm-Andr.) 'Gnome white', we grew plants either with one of six different fertilizer concentrations (fertilizer EC of $0.5,1.5,2.5,3.5,4.5$, or $5.5 \mathrm{dS} \cdot \mathrm{m}^{-1}$ ) or by maintaining a leachate $\mathrm{EC}$ close to $0.5,1.5,2.5$, 3.5 , 4.5, or $5.5 \mathrm{dS} \cdot \mathrm{m}^{-1}$. The leachate EC of plants fertilized with constant fertilizer concentrations increased throughout the experiment if the fertilizer EC was $2.5 \mathrm{dS} \cdot \mathrm{m}^{-1}$ or higher, was stable in the $1.5 \mathrm{dS} \cdot \mathrm{m}^{-1}$ treatment, and decreased in the $0.5 \mathrm{dS} \cdot \mathrm{m}^{-1}$ treatment. In treatments in which we tried to maintain the leachate EC constant, the leachate EC on average was within $0.2 \mathrm{dS} \cdot \mathrm{m}^{-1}$ of the target $\mathrm{EC}$. As a result of the acidic nature of the fertilizer, the $\mathrm{pH}$ of the growing medium decreased throughout the experiment with increasing leachate or fertilizer EC. When plants were fertilized with constant fertilizer concentrations, fertilizer solution EC of 0.52 and $1.24 \mathrm{dS} \cdot \mathrm{m}^{-1}$ were estimated to be optimal for begonia and petunia, respectively. When the growing medium was maintained at a constant EC, 1.0 and $1.7 \mathrm{dS} \cdot \mathrm{m}^{-1}$ were estimated to be optimal for begonia and petunia, respectively. Growth of both begonia and petunia was greatly inhibited when high fertilizer concentrations caused accumulation of soluble salts in the growing medium. Growth was reduced more by high fertilizer EC than by high leachate EC treatments. This difference probably occurred because superoptimal fertilizer concentrations resulted in very high leachate $\mathrm{EC}$ (up to $10.5 \mathrm{dS} \cdot \mathrm{m}^{-1}$ for petunia and $12.5 \mathrm{dS} \cdot \mathrm{m}^{-1}$ for begonia), which in turn inhibited growth. Periodic measurements of leachate EC can be a valuable tool in fertilizer management to prevent such excess buildup of salts in the growing medium.
\end{abstract}

Salt stress, caused by high levels of fertilizer salts in the growing medium, can greatly inhibit the growth of bedding plants. Salt accumulation in the root zone can affect plants because of osmotic stress, ionic imbalances, or specific nutrient toxicities (Dubey, 1996). Researchers previously have reported that higher than recommended leachate electrical conductivity (EC) can reduce plant growth (Gislerød and Mortensen, 1990; James and van Iersel, 2001; Kang and van Iersel, 2001; Nemali and van Iersel, 2004;

Received for publication 22 Aug. 2008. Accepted for publication 7 Oct. 2008.

${ }^{1}$ To whom reprint requests should be addressed; e-mail mvanier@uga.edu van Iersel, 1999; van Iersel and Kang, 2002). In general, the leachate EC increases with increasing fertilizer concentrations and these effects get more pronounced over time as fertilizer salts accumulate in the growing medium (van Iersel, 1999). Subirrigation may result in more problems with the accumulation of soluble salts in the growing medium than overhead watering, because excess salts are not leached from the growing medium (Kent and Reed, 1996).

Even when constant fertilizer concentrations are used, the growing medium EC will generally change over time because of such factors as changes in the frequency of fertigation and the balance between water and nutrient uptake by the plants. Environmental conditions that increase evapotranspiration such as low relative humidity or high temperatures but have less effect on plant nutrient uptake will increase salt accumulation in the growing medium unless fertigation practices are adjusted. For example, Kang and van Iersel (2001) found that the optimal fertilizer concentration for petunia growth decreased with increasing growing temperature. At high relative humidity, dry weight of begonia (Begonia $\times$ hiemalis Fotsch) was found to be higher at higher fertilizer concentrations (Gislerød and Mortensen, 1990). High relative humidity reduces the air-to-leaf vapor pressure deficit and thus the transpiration rate, increasing water use efficiency (Dewar, 1997). In general, environmental conditions that affect the water use efficiency of plants may also affect the optimal fertilizer concentration (Bugbee, 1995; Nemali and van Iersel, 2004). Therefore, fertilizer recommendations for bedding plants based on constant fertilizer concentrations may not be optimal; nutrient availability to the plants depends more on the amount of nutrients in the growing medium than on the amount of nutrients in the fertilizer solution.

Traditionally, recommendations for fertilization of bedding plants have focused on which concentration of fertilizer to apply. Recently, the focus of fertilization guidelines has shifted from recommending optimal fertilizer concentrations to maintaining the EC of the growing medium or the leachate within an optimal range (e.g., Cavins et al., 2000; Kang and van Iersel, 2002). Warncke and Krauskopf (1983) reported that a growing medium EC [as determined by the saturated medium extract method (SME)] of 0.75 to $2 \mathrm{dS} \cdot \mathrm{m}^{-1}$ is acceptable, whereas 2 to $3.5 \mathrm{dS} \cdot \mathrm{m}^{-1}$ is optimal for most greenhouse crops. Cavins et al. (2000) reported that a leachate EC of 1.0 to $2.6 \mathrm{dS} \cdot \mathrm{m}^{-1}$ (as determined by the pourthrough method) is optimal for annuals with low nutrient requirements, whereas 2.0 to $3.5 \mathrm{dS} \cdot \mathrm{m}^{-1}$ is optimal for greenhouse crops with medium nutrient requirements.

Growing medium-based guidelines have the advantage that they are less dependent on environmental conditions than optimal fertilizer concentrations. The optimal EC of the growing medium or leachate is likely to be much less sensitive to environmental conditions, including temperature, photosynthetic photon flux, and humidity, than the optimal fertilizer concentration (Gislerød and Mortensen, 1990; Kang and van Iersel, 2001; Nemali and van Iersel, 2004). Fertilizer recommendations based on the leachate EC give a better indication of the nutrient availability to the plants as well as the potential for salt stress than recommendations based on fertilizer concentrations. However, the disadvantages of trying to maintain a constant leachate EC include the requirement for regular and time-consuming measurements of leachate EC and the need to periodically adjust the fertilizer concentration to maintain the leachate $\mathrm{EC}$ within the required range.

Surprisingly, there has been no research comparing the effects of constant fertilizer 
concentration and constant leachate $\mathrm{EC}$ on the growth of floriculture crops. Therefore, the objective of this experiment was to determine whether maintaining a constant leachate EC results in better growth of petunia and wax begonia than constant fertilizer concentrations.

\section{Materials and Methods}

Plant material. Plug seedlings of wax begonia 'Cocktail mix' and petunia 'Gnome white' were obtained from Speedling Greenhouses (Blairsville, GA) and transplanted into $10-\mathrm{cm}$ square plastic pots $(510 \mathrm{~mL})$. The pots were filled with a soilless growing medium (MetroMix 300; Sun Gro Horticulture, Bellevue, WA). The medium composition and chemical properties were sphagnum peat, $10 \%$ to $20 \%$; vermiculite, $25 \%$ to $40 \%$; perlite, $5 \%$ to $15 \%$; bark ash, $0 \%$ to $10 \%$; pine bark, $25 \%$ to $45 \%$; and an initial $\mathrm{pH}$ and $\mathrm{EC}$ of 5.7 and $2.1 \mathrm{dS} \cdot \mathrm{m}^{-1}$, respectively (as determined with the SME method; Warncke, 1986). After transplanting, all plants were placed on $1.2 \times 2.4-\mathrm{m}^{2}$ ebb-and-flow benches (Midwest Gromaster, St. Charles, IL) in a double-layer polyethylene-covered greenhouse. The temperature set points for the greenhouse were $25{ }^{\circ} \mathrm{C}$ during the day and $20^{\circ} \mathrm{C}$ at night.

Treatments. All plants were subirrigated daily with a solution of water-soluble fertilizer. Water was pumped onto the benches using submersible pumps (NoKorode-2; Little Giant, Oklahoma City, OK). Approximately 6 min were required for the pumps to fill the trays with $\approx 3 \mathrm{~cm}$ of water and $9 \mathrm{~min}$ for the water to drain back into the holding tanks. The fertilizer solutions were stored in 210-L plastic barrels and were replenished as needed. The EC of the fertilizer solutions was measured weekly and adjusted by adding water or additional fertilizer as needed. The fertilizer EC also was adjusted every time the barrels were refilled.

Fertilizer solutions with an EC of 0.5, 1.5, $2.5,3.5,4.5$, or $5.5 \mathrm{dS} \cdot \mathrm{m}^{-1}$ were made using municipal water with an $\mathrm{EC}$ of $\approx 0.15 \mathrm{dS} \cdot \mathrm{m}^{-1}$ and a water-soluble $20 \mathrm{~N}-4.4 \mathrm{P}-16.6 \mathrm{~K}$ fertilizer (20-10-20 Peat-lite Special; The Scotts Co., Marysville, OH). This range of EC levels corresponded to nitrogen concentrations of $\approx 50,200,350,500,650$, and 800 $\mathrm{mg} \cdot \mathrm{L}^{-1}$. This range of fertilizer concentrations was chosen because the resulting solution EC values encompass the range of the leachate EC normally encountered during the production of bedding plants.

Plants were either subirrigated with the same fertilizer solution throughout the growing period ( $34 \mathrm{~d}$ for petunia, $49 \mathrm{~d}$ for begonia) or we tried to keep the leachate EC constant at $0.5,1.5,2.5,3.5,4.5$, or $5.5 \mathrm{dS} \cdot \mathrm{m}^{-1}$. To do this, leachate EC was measured twice weekly using the pourthrough method (see subsequently). All plants in a particular treatment were moved to another bench with higher or lower fertilizer EC if necessary to keep the leachate EC close to the desired value. After the leachate $\mathrm{EC}$ of a particular plant had been measured, that same plant was not used again for leachate collection, because the addition of water to the substrate to collect leachate could affect subsequent leachate measurements.

Measurements. Twice a week, leachate from three plants per experimental unit was measured using the pourthrough method (Wright, 1986). One hundred milliliters of water was poured on top of the growing medium and the first $20 \mathrm{~mL}$ of leachate was collected. Leachate EC and $\mathrm{pH}$ were measured with a $\mathrm{pH} / \mathrm{EC}$ meter (Checkmate; Corning, Corning, NY). Because the leachate composition and concentration depend on the moisture level of the growing medium (Cavins et al., 2005; Yeager et al., 1983), leachate $\mathrm{EC}$ and $\mathrm{pH}$ were always determined at 1 to $2 \mathrm{~h}$ after the last irrigation event. Because only the first $20 \mathrm{~mL}$ of leachate was collected, leachate $\mathrm{EC}$ and $\mathrm{pH}$ values reflect the $\mathrm{EC}$ and $\mathrm{pH}$ in the bottom part of the containers. The SD of the three replicates from one experimental unit averaged $0.3 \mathrm{dS} \cdot \mathrm{m}^{-1}$.

After collecting leachate, the shoot dry weight of two (begonia) or three (petunia) plants was determined (also twice a week).
Shoots were cut off at the substrate level and dried in a forced-air drying oven at $70^{\circ} \mathrm{C}$ for a minimum of $3 \mathrm{~d}$ before measuring dry weight.

Whole shoots from the final harvest were used for nutrient analysis and tissue nitrogen (N) and sulfur (S) were analyzed using a CNS 2000 analyzer (LECO Corp., St. Joseph, MI), whereas phosphorus, potassium, calcium, magnesium, aluminum, boron, copper, iron, magnesium, sodium, and zinc were determined by dry ashing and inductively coupled plasma spectrometry (Jones and Case, 1990). However, results of the tissue $\mathrm{N}$ analyses were extremely low (6.7 to $\left.12.0 \mathrm{mg} \cdot \mathrm{g}^{-1}\right)$, which is uncharacteristic for plants grown under these conditions. For example, James and van Iersel (2001) reported that petunias and begonias subirrigated with fertilizer solutions with ECs ranging from 0.15 (tap water) to $3.0 \mathrm{dS} \cdot \mathrm{m}^{-1}$ had shoot $\mathrm{N}$ concentrations between 50 and $60 \mathrm{mg} \cdot \mathrm{g}^{-1}$. The $\mathrm{N}$ sufficiency range for leaves of begonia is 20 to $60 \mathrm{mg} \cdot \mathrm{g}^{-1}$, whereas the survey range for petunia is 38.5 to $76.0 \mathrm{mg} \cdot \mathrm{g}^{-1}$ (Mills and Jones, 1996). Thus, if tissue $\mathrm{N}$ concentrations really had been close to $10 \mathrm{mg} \cdot \mathrm{g}^{-1}$, there
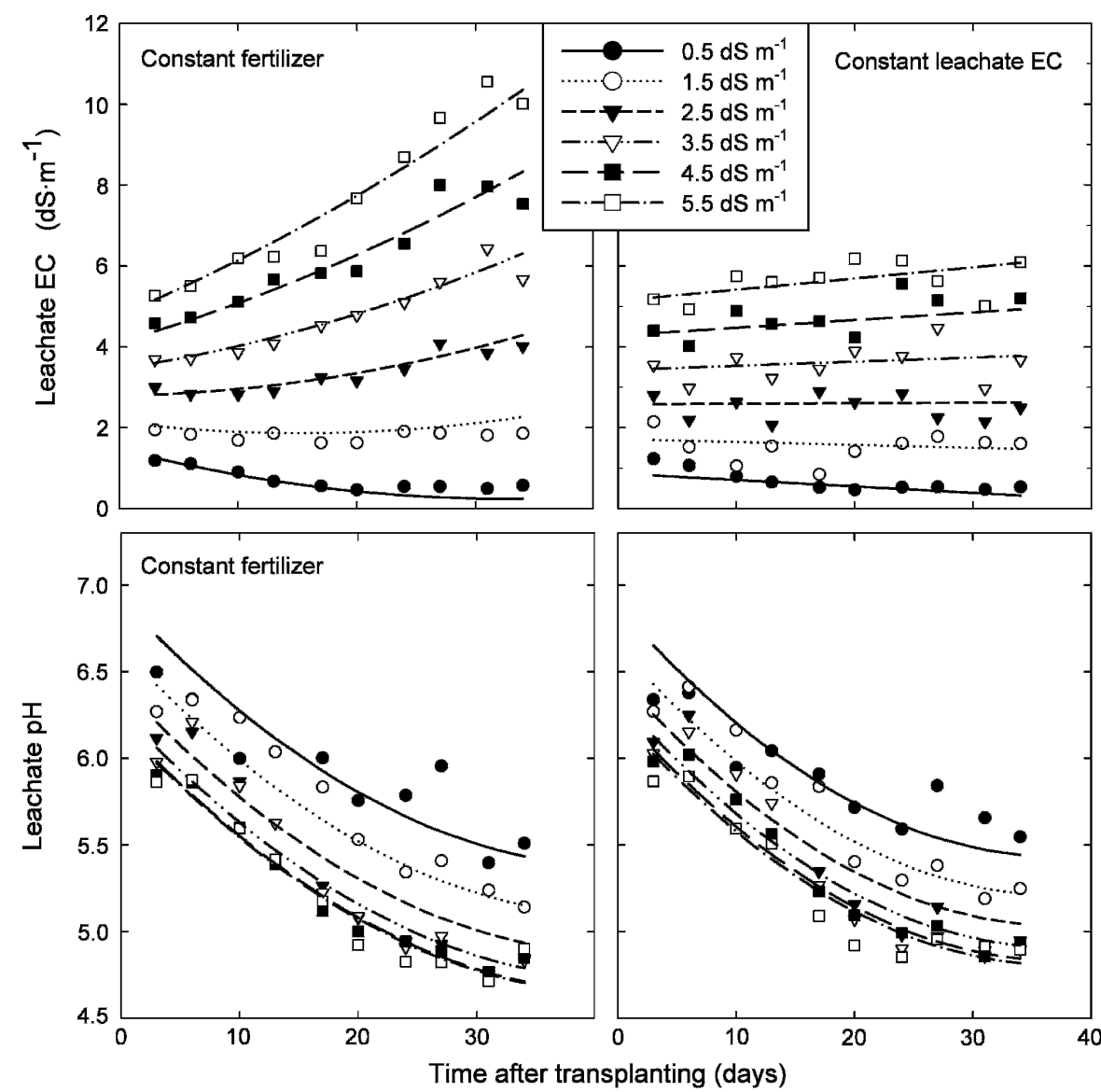

Fig. 1. The effect of constant fertilizer electrical conductivity (EC) (left) or management of the leachate EC to maintain stable levels (right) on leachate EC (top) and $\mathrm{pH}$ (bottom) over a 35-d period. Data shown are for petunia. Trends were similar for begonias. Regression analyses with constant fertilizer EC: leachate $\mathrm{pH}=7.08-0.352 \times \mathrm{EC}-0.0729 \times \mathrm{DAT}+0.0344 \times \mathrm{EC}^{2}+0.00086 \times \mathrm{DAT}^{2}\left(R^{2}=0.92\right)$, leachate $\mathrm{EC}=1.11+0.66 \times \mathrm{EC}-0.0956 \times \mathrm{DAT}+0.00116 \times \mathrm{DAT}^{2}+0.0400 \times \mathrm{EC} \times \mathrm{DAT}\left(R^{2}=0.99\right)$, and with constant growing medium EC: leachate $\mathrm{pH}=7.01-0.273 \times \mathrm{EC}-0.0775 \times \mathrm{DAT}+0.0246 \times$ $\mathrm{EC}^{2}+0.00104 \times \mathrm{DAT}^{2}\left(R^{2}=0.92\right)$, leachate $\mathrm{EC}=0.439+0.854 \times \mathrm{EC}-0.0203 \times \mathrm{DAT}+0.00872 \times \mathrm{EC}$ $\times$ DAT $\left(R^{2}=0.96\right)$. DAT $=$ days after transplanting. 
likely would have been severe visual deficiency symptoms, which was not the case. Likewise, tissue $\mathrm{S}$ concentrations seemed unrealistically low ( 0.7 to $1.5 \mathrm{mg} \cdot \mathrm{g}^{-1}$, whereas normal concentrations for these plants would be 2 to $8 \mathrm{mg} \cdot \mathrm{g}^{-1}$ ). Reanalysis of the samples resulted in similar values, and the $\mathrm{N}$ and $\mathrm{S}$ tissue analyses were considered unreliable and are not presented.

Experimental design and data analysis. The experimental design was a randomized complete block with a split plot (constant fertilizer or growing medium EC), six treatments (EC levels), repeated measures (at different times during the experiment), and two replications. The experimental unit was a group of 30 petunias or begonias at the start of the experiment, and the number of plants in each experimental unit decreased as plants were harvested for dry weight determinations. The total number of plants used in this experiment was 1440 (30 plants/experimental unit $\times$ two EC management methods $\times$ six EC levels $\times$ two species $\times$ two replications). Data were analyzed by regression analysis using Statistical Analysis Software (SAS Institute Inc., Cary, NC). To determine the effects of fertilizer or growing medium EC, a polynomial model, including an interaction term, was used:

$$
\begin{aligned}
\mathrm{X}= & \beta_{0}+\beta_{1} \times E C+\beta_{2} \times \mathrm{DAT}+\beta_{3} \\
& \times \mathrm{EC}^{2}+\beta_{4} \times \mathrm{DAT}^{2}+\beta_{5} \times \mathrm{EC}^{3}+\beta_{6} \\
& \times \mathrm{EC} \times \mathrm{DAT}
\end{aligned}
$$

where: $X=\ln$ (dry weight), leachate $\mathrm{pH}$, or leachate $\mathrm{EC} ; \beta_{0}, . ., \beta_{6}$ are regression parameters; EC is either the EC of the fertilizer solution or the target EC of the leachate; and DAT is days after transplanting. Nonsignificant components in the regression equation $(P>0.05)$ were eliminated using backward selection.

The regression results were used to estimate the EC resulting in maximum dry weight by using the regression equation for $\ln$ (dry weight) and taking the first derivative with regard to $\mathrm{EC}$ and determining at which $\mathrm{EC}$ this derivative equaled zero to find the maximum.

To compare final dry weight data among all treatments, the data were analyzed using analysis of variance, whereas tissue nutrient concentrations were analyzed using linear and quadratic regression $(P<0.05)$. In all cases, the data for the two species were analyzed separately, because data were collected on different dates. Mean separation for the dry weight data were done using Fisher's protected least significant difference (0.05).

\section{Results and Discussion}

Leachate electrical conductivity and $\mathrm{pH}$. In general, leachate EC increased with increasing fertilizer concentration in the subirrigation system (petunia data shown in Fig. 1; data for begonia are not shown but were similar). The leachate EC of petunias fertilized with constant fertilizer concentrations increased throughout the experiment if the fertilizer solution EC was $2.5 \mathrm{dS} \cdot \mathrm{m}^{-1}$ or higher, was stable in the $1.5 \mathrm{dS} \cdot \mathrm{m}^{-1}$ treatment, and decreased in the $0.5 \mathrm{dS} \cdot \mathrm{m}^{-1}$ treatment (Fig. 1).

The steady increase in the leachate EC in treatments with a fertilizer solution EC of 2.5 $\mathrm{dS} \cdot \mathrm{m}^{-1}$ or higher indicates that more fertilizer was added to the growing medium than was taken up by the plants. In the treatment in which plants were irrigated with a solution with an EC of $5.5 \mathrm{dS} \cdot \mathrm{m}^{-1}$, the leachate EC eventually was slightly above $10 \mathrm{dS} \cdot \mathrm{m}^{-1}$, indicating a large accumulation of solutes in the growing medium.

An increase in leachate EC with increasing fertilizer concentrations throughout the experiment is consistent with previous findings (Gislerød and Mortensen, 1990; James and van Iersel, 2001; Kang and van Iersel, 2001; Nemali and van Iersel, 2004; van Iersel, 1999; van Iersel and Kang, 2002). In subirrigation systems, salts are not leached out of the containers and excess salts generally accumulate near the top of the growing medium, where evaporation occurs (Argo and Biernbaum, 1996). Salts can also accumulate in the middle and bottom layers of the growing medium if the fertilizer concentration is high (Kent and Reed, 1996), as evidently was the case in this experiment.

The decrease in the leachate EC with the $0.5 \mathrm{dS} \cdot \mathrm{m}^{-1}$ fertilizer solution indicates either that the plants were taking up more nutrients than were applied and/or that the nutrients in the growing medium accumulated in the top layer of the growing medium.

In treatments in which we tried to maintain a stable leachate EC, the leachate EC generally was close to the target $\mathrm{EC}$ and averaged $0.68,1.52,2.49,3.57,4.77$, and $5.62 \mathrm{dS} \cdot \mathrm{m}^{-1}$ in the $0.5,1.5,2.5,3.5,4.5$, and $5.5 \mathrm{dS} \cdot \mathrm{m}^{-1}$ treatments, respectively, over the experimental period (Fig. 1). Treatment effects on the leachate EC of begonias were similar (data not shown).

The leachate $\mathrm{pH}$ decreased throughout the experiment and decreased with increasing EC up to an EC of $3.5 \mathrm{dS} \cdot \mathrm{m}^{-1}$ (Fig. 1). There was little difference in the $\mathrm{pH}$ among the 3.5
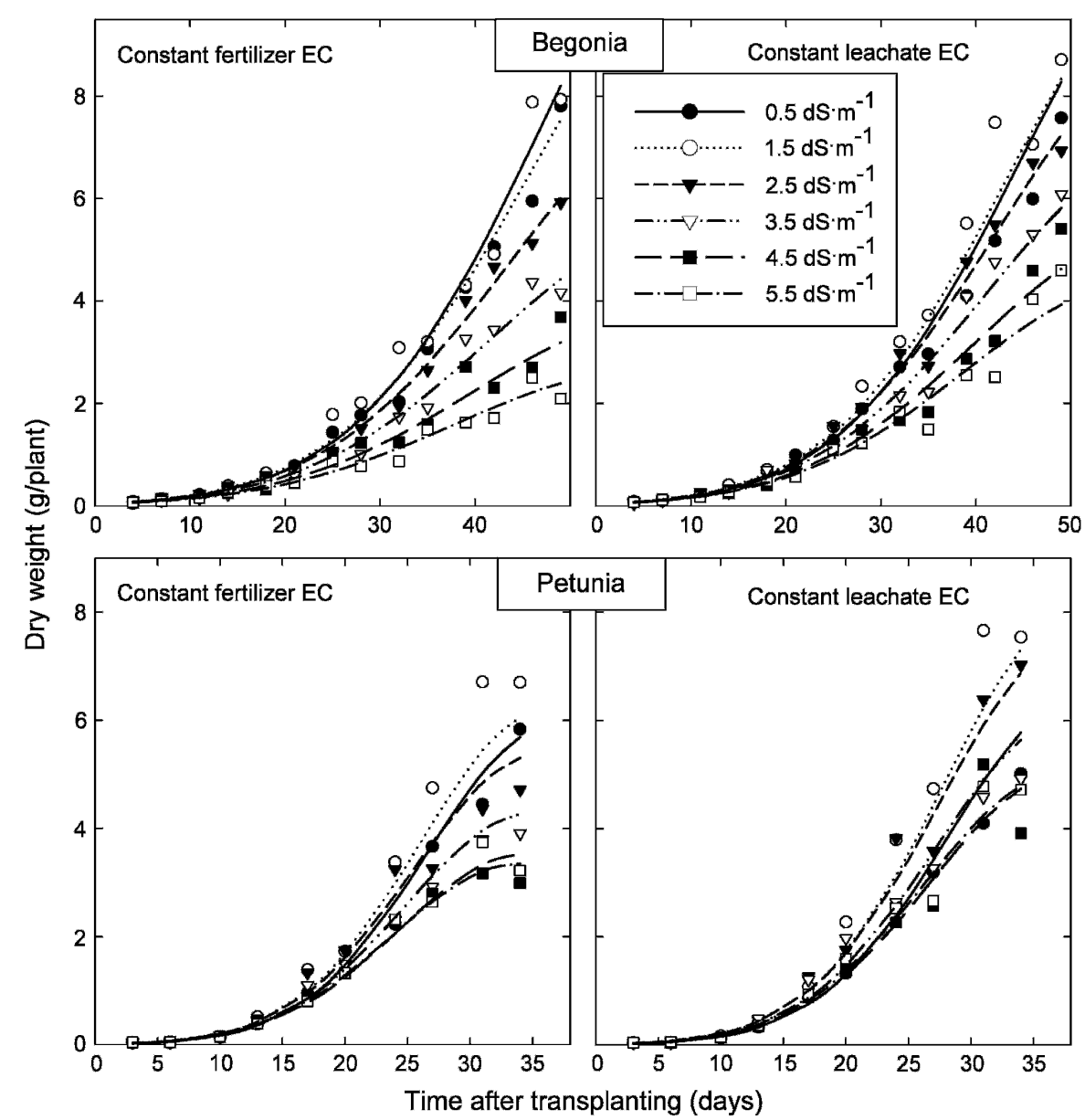

Fig. 2. The effect of constant fertilizer electrical conductivity (EC) (left) or management of the leachate EC to try to maintain stable levels (right) on the dry weight (DW) of begonia (top) and petunia (bottom) throughout their development. Regression analysis for begonias grown with constant fertilizer EC: $\ln (\mathrm{DW})=-3.486+0.177 \times \mathrm{DAT}+0.361 \times \mathrm{EC}-0.00130 \times \mathrm{DAT}^{2}-0.115 \times \mathrm{EC}^{2}+0.0100 \times \mathrm{EC}^{3}-$ $0.00506 \times \mathrm{EC} \times \mathrm{DAT}\left(R^{2}=0.98\right)$ and constant leachate $\mathrm{EC}: \ln (\mathrm{DW})=-3.628+0.188 \times \mathrm{DAT}+0.388 \times$ $\mathrm{EC}-0.00148 \times \mathrm{DAT}^{2}-0.127 \times \mathrm{EC}^{2}+0.0117 \times \mathrm{EC}^{3}-0.00337 \times \mathrm{EC} \times \mathrm{DAT}\left(R^{2}=0.98\right)$. Regression analysis for petunias grown with constant fertilizer EC: $\ln (\mathrm{DW})=-5.178+0.369 \times \mathrm{DAT}+0.556 \times \mathrm{EC}$ $-0.00500 \times \mathrm{DAT}^{2}-0.181 \times \mathrm{EC}^{2}+0.0185 \times \mathrm{EC}^{3}-0.00564 \times \mathrm{EC} \times \mathrm{DAT}\left(R^{2}=0.98\right)$, and constant leachate $\mathrm{EC}: \ln (\mathrm{DW})=-5.240+0.350 \times \mathrm{DAT}+0.799 \times \mathrm{EC}-0.00448 \times \mathrm{DAT}^{2}-0.270 \times \mathrm{EC}^{2}+0.0269$ $\times \mathrm{EC}^{3}-0.00326 \times \mathrm{EC} \times \mathrm{DAT}\left(R^{2}=0.98\right) . \mathrm{DAT}=$ days after transplanting. 
to $5.5 \mathrm{dS} \cdot \mathrm{m}^{-1}$ treatments in both the constant leachate EC and constant fertilizer EC treatments. The decrease in $\mathrm{pH}$ with increasing fertilizer concentrations and time after transplanting is the result of the acidic nature of the fertilizer $\left(203 \mathrm{~g} \cdot \mathrm{kg}^{-1} \mathrm{CaCO}_{3}\right.$ equivalents) and similar to our previous observations (James and van Iersel, 2001; Kang and van Iersel, 2001; Nemali and van Iersel, 2004).

The recommended range for the $\mathrm{pH}$ of the growing medium for most floricultural crops is 5.4 to 6.5 (Bailey and Bilderback, 1997; Lang, 1996). In our experiment, in both the constant fertilizer and leachate $\mathrm{EC}$ treatments, the $\mathrm{pH}$ was within or near this range throughout the experiment when treated with 0.5 and $1.5 \mathrm{dS} \cdot \mathrm{m}^{-1}$. In the treatments with an EC of $2.5 \mathrm{dS} \cdot \mathrm{m}^{-1}$ or higher, the $\mathrm{pH}$ was within or near the recommended range during the first 2 weeks of the growing period but dropped to 4.9 near the end of the growing period (Fig. 1). Treatment effects on the $\mathrm{pH}$ of begonias were similar (data not shown). No visual symptoms of micronutrient toxicities or deficiencies were observed, but we cannot rule out that the lower-than-optimal $\mathrm{pH}$ may have reduced growth in some treatments.

Plant growth. Dry weight of the plants increased rapidly throughout the experiment, and it took $\approx 20 \mathrm{~d}$ before differences in dry weight among treatments became apparent (Fig. 2). For begonias, fertilizer or leachate ECs of 0.5 and $1.5 \mathrm{dS} \cdot \mathrm{m}^{-1}$ generally resulted in the highest dry weight during the latter part of the study. For petunias, the highest dry weight with constant fertilizer ECs generally occurred in the $1.5 \mathrm{dS} \cdot \mathrm{m}^{-1}$ treatment followed by 0.5 and $2.5 \mathrm{dS} \cdot \mathrm{m}^{-1}$, whereas 1.5 and $2.5 \mathrm{dS} \cdot \mathrm{m}^{-1}$ were the optimal leachate ECs.

At the end of the study (after $34 \mathrm{~d}$ for petunia and $49 \mathrm{~d}$ for begonia), there were no differences in dry weight among the constant fertilizer and leachate EC treatments that resulted in maximum dry weight (leachate or fertilizer ECs of 0.5 or $1.5 \mathrm{dS} \cdot \mathrm{m}^{-1}$ for begonia and a fertilizer EC of $1.5 \mathrm{dS} \cdot \mathrm{m}^{-1}$ or leachate $\mathrm{EC}$ of 1.5 or $2.5 \mathrm{dS} \cdot \mathrm{m}^{-1}$ for petunia; Fig. 3). However, at superoptimal EC levels, high fertilizer ECs inhibited growth more than high leachate ECs (Fig. 3). This is not surprising, because high fertilizer ECs resulted in much higher leachate ECs (up to $10.5 \mathrm{dS} \cdot \mathrm{m}^{-1}$ for petunia and $12.5 \mathrm{dS} \cdot \mathrm{m}^{-1}$ for begonia) than high leachate EC treatments (Fig. 1).

Using the equations fitted to the data in Figure 2, it was determined that the optimal EC of the fertilizer and leachate for wax begonia and petunia decreased throughout the experiment (Fig. 4). In both species, this decrease in optimal EC was greater with constant fertilizer EC than with constant leachate EC. Optimal fertilizer EC for begonia was $\approx 1.8,1.0$, and $0.5 \mathrm{dS} \cdot \mathrm{m}^{-1}$, whereas optimal leachate EC was $1.9,1.4$, and 1.1 $\mathrm{dS} \cdot \mathrm{m}^{-1}$ at 10,30 , and $50 \mathrm{~d}$ after transplanting, respectively. Optimal fertilizer EC for petunia was $\approx 2.3,1.7$, and $1.2 \mathrm{dS} \cdot \mathrm{m}^{-1}$, whereas optimal leachate EC was 2.2, 2.0, and 1.7

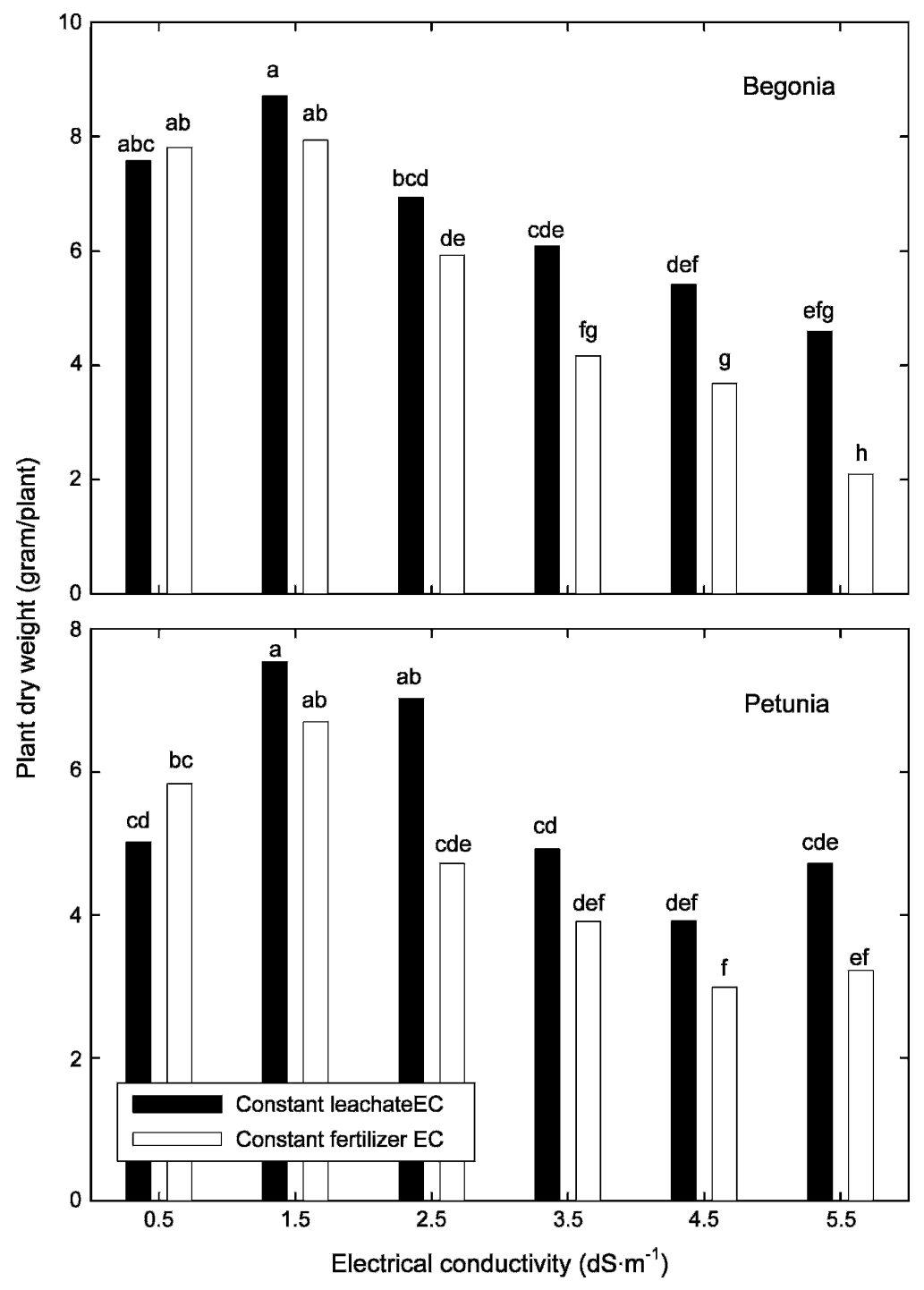

Fig. 3. Final dry weight of begonias and petunias watered with fertilizer solutions with an electrical conductivity (EC) of 0.5 to $5.5 \mathrm{dS} \cdot \mathrm{m}^{-1}$ or fertigated to maintain the leachate EC as stable as possible. Means within a species with the same letter are not significantly different from each other according to Fisher's least significant difference (0.05).

$\mathrm{dS} \cdot \mathrm{m}^{-1}$ at 3,15 , and $35 \mathrm{~d}$ after transplanting, respectively.

It is important to note that these decreases in optimal EC do not imply that growers should try to gradually reduce the fertilizer or leachate EC over the course of the production period. Rather, these results indicate that to grow begonias or petunias for a short period, a higher EC is optimal than for longer-term production, i.e., the curves in Figure 4 indicate which fertilizer or leachate EC likely would have resulted in the highest dry weight, assuming that this particular EC level had been maintained up to that particular point in time. Data from this experiment cannot be used to determine whether gradually decreasing fertilizer or leachate EC would beneficial, because no such treatments were included.

Cavins et al. (2000) compiled leachate EC recommendations for a wide variety of species and reported that a leachate EC of 1.0 to $2.6 \mathrm{dS} \cdot \mathrm{m}^{-1}$ is optimal for annuals with low nutrient requirements (including begonia), whereas 2.0 to $3.5 \mathrm{dS} \cdot \mathrm{m}^{-1}$ is optimal for greenhouse crops with medium nutrient requirements (including petunia). The estimated optimal leachate ECs at the end of our experiment are either at the low end (begonia) or slightly below these ranges (petunia). This may have been partly the result of the low EC of our water supply $\left(0.15 \mathrm{dS} \cdot \mathrm{m}^{-1}\right)$.

James and van Iersel (2001) found that the dry weight of begonia at 7 weeks after transplanting was highest at a fertilizer solution EC of $1.7 \mathrm{dS} \cdot \mathrm{m}^{-1}$. This fertilizer concentration resulted in a leachate $\mathrm{EC}$ of $\approx 3.8 \mathrm{dS} \cdot \mathrm{m}^{-1}$ after 7 weeks. They also found that the dry weight of begonia at 7 weeks after transplanting was acceptable when fertilizer solutions with an EC of 1.0 to $2.4 \mathrm{dS} \cdot \mathrm{m}^{-1}$ were used. These fertilizer ECs resulted in leachate ECs of $\approx 2$ to $6 \mathrm{dS} \cdot \mathrm{m}^{-1}$ after a 7 -week growing period. Nemali and van Iersel (2004) found that the optimal range of fertilizer EC for shoot dry weight of wax begonia ranged from 
0.65 to $2.0 \mathrm{dS} \cdot \mathrm{m}^{-1}$, resulting in a leachate $\mathrm{EC}$ ranging from 1.4 to $2.8 \mathrm{dS} \cdot \mathrm{m}^{-1}$. The optimal leachate EC for wax begonia obtained in our

Fig. 4. Optimal fertilizer or leachate electrical conductivity (EC) of petunias and begonias. Optimal ECs were determined by taking the first derivative with regard to EC from the regression equations in Figure 2 and determining at which EC this derivative was 0.

reported by James and van Iersel (2001) and Nemali and van Iersel (2004).

James and van Iersel (2001) found that the maximum growth of petunia occurred with a current experiment was lower than those

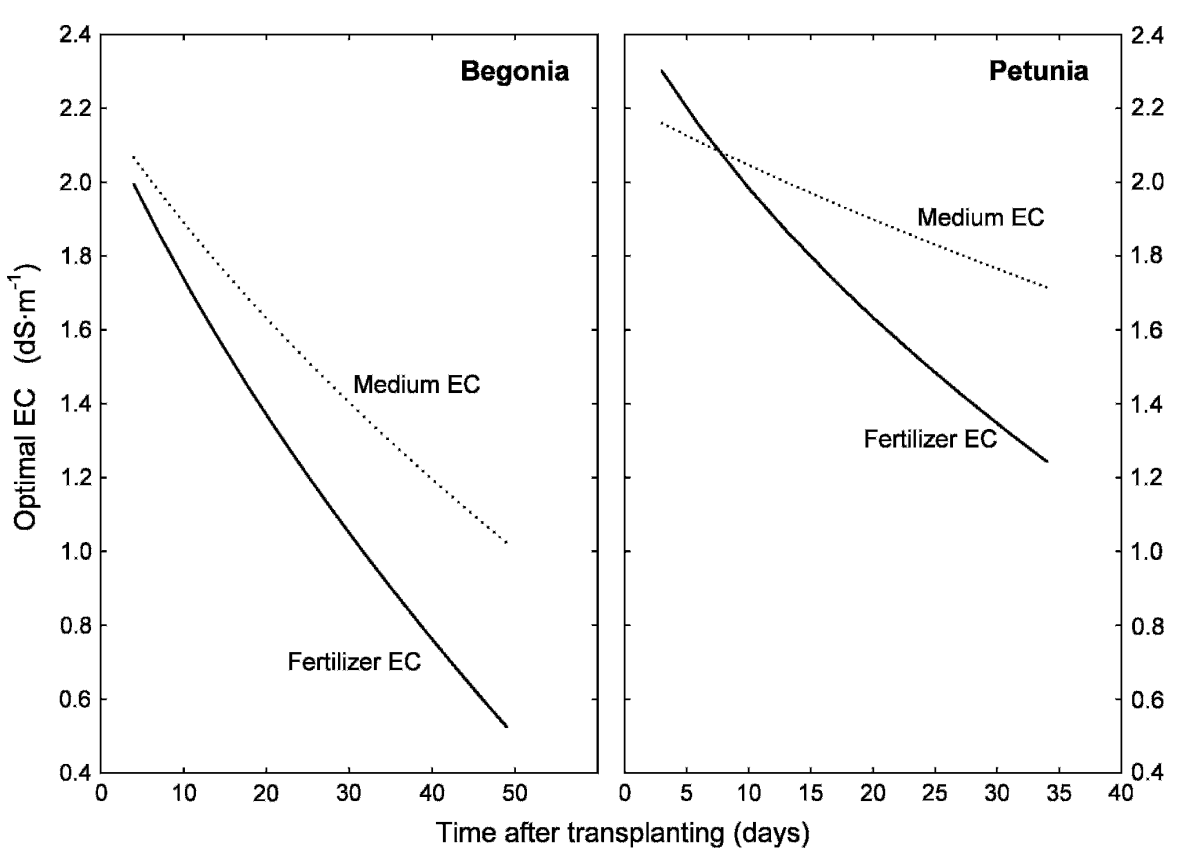

Table 1. Shoot tissue nutrient concentrations of begonias and petunias irrigated with fertilizer solutions with an electrical conductivity (EC) of 0.5 to $5.5 \mathrm{dS} \cdot \mathrm{m}^{-1}$ or fertigated to maintain the leachate EC as stable as possible. ${ }^{z}$

\begin{tabular}{|c|c|c|c|c|c|c|c|c|c|c|}
\hline \multirow{2}{*}{$\begin{array}{l}\mathrm{EC} \\
\left(\mathrm{dS} \cdot \mathrm{m}^{-1}\right)\end{array}$} & $\mathrm{P}$ & $\mathrm{K}$ & $\mathrm{Ca}$ & $\mathrm{Mg}$ & B & $\mathrm{Cu}$ & $\mathrm{Fe}$ & $\mathrm{Mn}$ & Mo & $\mathrm{Zn}$ \\
\hline & \multicolumn{4}{|c|}{ 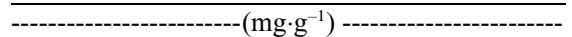 } & \multicolumn{6}{|c|}{ 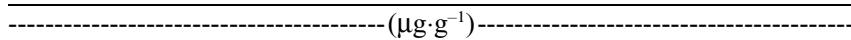 } \\
\hline 0.5 & 6.7 & 58.3 & 10.1 & 5.57 & 25 & 9.6 & 145 & 184 & 0.75 & 34 \\
\hline 3.5 & 9.1 & 71.6 & 10.4 & 7.39 & 29 & 11.0 & 219 & 177 & 0.12 & 59 \\
\hline 4.5 & 5.8 & 28.0 & 7.2 & 5.07 & 20 & 8.8 & 98 & 217 & 0.12 & 51 \\
\hline 5.5 & 6.8 & 29.3 & 5.6 & 3.21 & 25 & 8.5 & 108 & 166 & 0.20 & 44 \\
\hline 0.5 & 6.5 & 56.9 & 10.3 & 5.96 & 23 & 9.1 & 160 & 186 & 0.61 & 32 \\
\hline 1.5 & 8.8 & 55.0 & 10.8 & 8.06 & 29 & 22.8 & 190 & 187 & 0.28 & 48 \\
\hline 2.5 & 8.1 & 59.0 & 10.6 & 7.63 & 30 & 10.1 & 210 & 231 & 0.17 & 60 \\
\hline 3.5 & 7.1 & 44.8 & 7.6 & 5.62 & 24 & 8.6 & 127 & 132 & 0.12 & 52 \\
\hline 4.5 & 6.5 & 28.8 & 6.1 & 4.01 & 21 & 9.5 & 103 & 156 & 0.25 & 49 \\
\hline \multirow{2}{*}{5.5} & 7.1 & 27.4 & 6.6 & 3.76 & 26 & 9.1 & 120 & 200 & 0.43 & 51 \\
\hline & & $\mathrm{L}$ & $\mathrm{L}$ & $\mathrm{L}$ & & & $\mathrm{L}$ & & Q & $\mathrm{Q}$ \\
\hline 3.5 & 4.6 & 25.1 & 7.4 & 6.39 & 56 & 12.1 & 333 & 309 & 0.12 & 52 \\
\hline 4.5 & 5.0 & 25.6 & 7.8 & 5.71 & 56 & 16.9 & 226 & 322 & 0.12 & 55 \\
\hline \multirow[t]{2}{*}{5.5} & 4.8 & 23.3 & 7.6 & 5.74 & 56 & 16.3 & 199 & 297 & 0.12 & 55 \\
\hline & & $\mathrm{Q}$ & & & Q & $\mathrm{L}$ & & & $\mathrm{Q}$ & $\mathrm{L}$ \\
\hline \multicolumn{11}{|c|}{ Begonia, constant fertilizer EC } \\
\hline 0.5 & 3.6 & 20.0 & 7.3 & 6.89 & 28 & 9.5 & 88 & 358 & 3.27 & 31 \\
\hline 1.5 & 5.0 & 26.7 & 8.3 & 6.13 & 51 & 11.3 & 307 & 313 & 0.21 & 48 \\
\hline 2.5 & 5.3 & 26.7 & 6.8 & 5.25 & 59 & 11.2 & 165 & 276 & 0.12 & 45 \\
\hline 3.5 & 5.2 & 24.9 & 7.4 & 5.93 & 66 & 17.8 & 176 & 174 & 0.12 & 55 \\
\hline 4.5 & 4.9 & 25.4 & 7.6 & 5.36 & 59 & 17.5 & 162 & 212 & 0.22 & 52 \\
\hline \multirow[t]{2}{*}{5.5} & 6.2 & 26.0 & 8.8 & 5.96 & 74 & 22.1 & 187 & 334 & 0.23 & 69 \\
\hline & $\mathrm{L}$ & & & & & $\mathrm{L}$ & Q & Q & Q & $\mathrm{L}$ \\
\hline Sufficiency range & $2.9-7.5$ & $22.5-60$ & $0-31$ & $3-8.8$ & $20-75$ & $7-33$ & $50-200$ & $45-200$ & $0.5-0.8$ & $25-100$ \\
\hline
\end{tabular}

${ }^{\mathrm{z}}$ Data were analyzed using linear and quadratic regression analysis. L and Q indicate significant linear and quadratic effects, respectively $(P<0.05)$. Survey and sufficiency ranges are given for comparison and are taken from Mills and Jones (1996).

HortScience Vol. 44(1) February 2009 fertilizer EC of $2.2 \mathrm{dS} \cdot \mathrm{m}^{-1}$ and that plants grew well when the leachate $\mathrm{EC}$ at the end of the production cycle was between 2.3 to 5.2 $\mathrm{dS} \cdot \mathrm{m}^{-1}$. Kang and van Iersel (2001) found that the petunia growth was best when the final leachate EC was 3 to $4 \mathrm{dS} \cdot \mathrm{m}^{-1}$, irrespective of growing temperature, whereas the optimal fertilizer EC decreased with increasing temperature. Nemali and van Iersel (2004) found that the optimal range of fertilizer EC for shoot dry weight accumulation of petunia ranged from 1.2 to $2.8 \mathrm{dS} \cdot \mathrm{m}^{-1}$. The results obtained in our experiment are similar to those obtained by James and van Iersel (2001) and Nemali and van Iersel (2004) but lower than those reported by Kang and van Iersel (2001). This difference may be the result of different environmental conditions during these experiments. As pointed out by Gislerød and Mortensen (1990) and Kang and van Iersel (2001), optimal fertilizer concentrations for bedding plant productions are dependent on environmental conditions. In addition, in previous studies, leachate EC changed throughout the growing period, which makes it difficult to compare leachate EC values from previous research with our current study in which leachate EC was maintained relatively constant (in half of the treatments).

Nutrient analysis. In general, tissue macronutrient concentrations of petunia were affected more than those of begonia (Table 
1). There was a large decrease in potassium (K) concentrations of petunia with increasing fertilizer or leachate EC, whereas effects on begonia $\mathrm{K}$ concentration were much smaller. Petunia calcium $(\mathrm{Ca})$ and magnesium $(\mathrm{Mg})$ concentrations also decreased at higher leachate or fertilizer $\mathrm{EC}$, whereas $\mathrm{Ca}$ and $\mathrm{Mg}$ concentrations of begonia were unaffected by the treatments (Table 1). There were few consistent treatment effects on tissue phosphorus $(\mathrm{P})$ concentrations; tissue $\mathrm{P}$ of begonia increased with increasing fertilizer EC but was unaffected by leachate EC treatments.

The micronutrients most affected by the treatments were copper $(\mathrm{Cu})$ and molybdenum (Mo). Begonia $\mathrm{Cu}$ concentrations almost doubled as fertilizer or leachate EC increased from 0.5 to $5.5 \mathrm{dS} \cdot \mathrm{m}^{-1}$. This increase in tissue $\mathrm{Cu}$ concentrations may be related to both the increased supply of $\mathrm{Cu}$ at higher fertilizer rates and the lower $\mathrm{pH}$ that occurred with high fertilizer or leachate ECs, because the availability of $\mathrm{Cu}$ increases at low pH (Havlin et al., 2004). However, there were no similar effects of $\mathrm{Cu}$ concentrations of petunia. There was a large decrease in tissue Mo concentrations of begonia as leachate or fertilizer EC was increased above $0.5 \mathrm{dS} \cdot \mathrm{m}^{-1}$. This also may have been related to $\mathrm{pH}$, because Mo availability increases with increasing pH (Havlin et al., 2004). A similar, but less dramatic, response was seen in petunia (Table 1).

\section{Conclusions}

High-quality bedding plants can be grown successfully either with constant fertilizer concentrations or by maintaining the leachate EC at a constant level. However, growth of both begonia and petunia is greatly inhibited when high fertilizer concentrations cause accumulation of soluble salts in the growing medium. Periodic measurements and adjustments of leachate EC will help prevent this accumulation and are therefore a valuable tool in fertilizer management. The optimal leachate $\mathrm{EC}$ is $\approx 0.9$ to $1.3 \mathrm{dS} \cdot \mathrm{m}^{-1}$ for begonia and 1.5 to $1.9 \mathrm{dS} \cdot \mathrm{m}^{-1}$ for petunia. In both species, optimal EC of the fertilizer and leachate decreased throughout the experiment, suggesting that when plants are grown for longer periods, lower fertility levels may be optimal.

\section{Literature Cited}

Argo, W.R. and J.A. Biernbaum. 1996. Availability and persistence of macronutrients from lime and preplant nutrient charge fertilizers in peatbased root media. J. Amer. Soc. Hort. Sci. 121:453-460.

Bailey, D.A. and T. Bilderback. 1997. Alkalinity control for irrigation water used in nurseries and greenhouses. Hort. Info. Lflt. 558. North Carolina Coop. Ext. Serv.

Bugbee, B. 1995. Nutrient management in recirculating hydroponic culture, p. 15-30. In: Proc. 16 th Annu. Conf. on Hydroponics. Hydroponic Soc. Amer., San Ramon, CA.

Cavins, T.J., B.E. Whipker, and W.C. Fonteno. 2005. Timing of PourThru affects $\mathrm{pH}$, electrical conductivity, and leachate volume. Commun. Soil Sci. Plant Anal. 36:1573-1581.

Cavins, T.J., B.E. Whipker, W.C. Fonteno, B. Harden, I. McCall, and J.L. Gibson. 2000. Monitoring and managing $\mathrm{pH}$ and $\mathrm{EC}$ using the pourthru extraction method. Hort. Info. Lflt. 590. North Carolina Coop. Ext. Serv., Raleigh, NC.

Dewar, R.C. 1997. A simple model of light and water use evaluated for Pinus radiata. Tree Physiol. 17:259-265.

Dubey, R.S. 1996. Photosynthesis in plants under stressful conditions, p. 859-875. In: Pessarakli, M. (ed.). Handbook of photosynthesis. Marcel Dekker, Inc., New York, NY.

Gislerød, H.R. and L.M. Mortensen. 1990. Relative humidity and nutrient concentration affect nutrient uptake and growth of Begonia $\times$ hiemalis. HortScience 25:524-526.

Havlin, J.L., J.D. Beaton, S.L. Tisdale, and W.L. Nelson. 2004. Soil fertility and fertilizers. An introduction to nutrient management. PrenticeHall, Upper Saddle River, NJ.

James, E.C. and M.W. van Iersel. 2001. Fertilizer concentration affects growth and flowering of subirrigated petunias and begonias. HortScience 36:40-44.
Jones, J.B. and V.W. Case. 1990. Sampling, handling, and analyzing plant tissue samples, $\mathrm{p}$. 389-427. In: Westerman, R.L. (ed.). Soil testing and plant analysis. Soil Sci. Soc. Amer., Madison, WI.

Kang, J.G. and M.W. van Iersel. 2001. Interactions between temperature and fertilizer concentration affect growth of subirrigated petunias. J. Plant Nutr. 24:753-765.

Kang, J.G. and M.W. van Iersel. 2002. Nutrient solution concentration affects growth of subirrigated bedding plants. J. Plant Nutr. 25:387403.

Kent, M.W. and D.W. Reed. 1996. Nitrogen nutrition of New Guinea impatiens 'Barbados' and Spathiphyllum 'Petite' in a subirrigation system. J. Amer. Soc. Hort. Sci. 121:816819.

Lang, H.J. 1996. Growing media testing and interpretation, p. 123-139. In: Reed, D.W. (ed.). Water, media, and nutrition for greenhouse crops. Ball Publishing, Batavia, IL.

Mills, H.A. and J.B. Jones. 1996. Plant analysis handbook. II. A practical sampling, preparation, analysis, and interpretation guide. MicroMacro Publishing, Athens, GA.

Nemali, K.S. and M.W. van Iersel. 2004. Light intensity and fertilizer concentration: I. Estimating optimal fertilizer concentrations from water-use efficiency of wax begonia. HortScience 39:1287-1292.

van Iersel, M.W. 1999. Fertilizer concentration affects growth and nutrient composition of subirrigated pansies. HortScience 34:660-663.

van Iersel, M.W. and J.G. Kang. 2002. Nutrient solution concentration affects whole-plant $\mathrm{CO}_{2}$ exchange and growth of subirrigated pansy. J. Amer. Soc. Hort. Sci. 127:423-429.

Warncke, D.D. 1986. Analyzing greenhouse growth media by the saturation extraction method. HortScience 21:223-225.

Warncke, D.D. and D.M. Krauskopf. 1983. Greenhouse growth media: Testing and nutrition guidelines. Michigan State Univ. Coop. Ext. Serv. Bul. E.

Wright, R.D. 1986. The pour-through nutrient extraction procedure. HortScience 21:227229.

Yeager, T.H., R.D. Wright, and S.S. Donahue. 1983. Comparison of pour-through and saturated pine bark extract, $\mathrm{N}, \mathrm{P}, \mathrm{K}$, and $\mathrm{pH}$ levels. J. Amer. Soc. Hort. Sci. 108:112-114. 